\title{
Transcendental Paradigm In Pancasila
}

\author{
Arie Purnomosidi \\ Law Faculty of Universitas Surakarta \\ arie.poernomosidi@gmail.com
}

DOI: https://doi.org/10.23917/jtl.v1i2.9414

\section{Submission \\ Track: \\ Received: \\ 02 Desember 2019 \\ Final Revision: \\ 4 Februari 2020 \\ Available online: \\ 14 Februari 2020 \\ Corresponding \\ Author:}

Arie Purnomosidi

arie.poernomosidi@gmail.com

\begin{abstract}
Purpose: This article aims to elucidate how the transcendental paradigm in Pancasila.
\end{abstract}

Methodology: The writing of this article used the doctrinal method by using philosophical and theoretical approaches.

Finding: Indonesian law tends to be paradigmatic towards power. This condition caused a materialistic and atheistic way of law. Therefore, it has evoked a crisis in law. Supposedly, Pancasila is a legal basis that is based on the spirit of the nation (volkgeist) of Indonesia. Pancasila is a law that is under the characteristics of people in Indonesia, which are more monodualistic and pluralistic in nature. Therefore, Pancasila contains transcendental values, which are sourced from divine values in religious, ethical, and moral law. The transcendental paradigm in Pancasila can be observed from the opening of the 1945 Constitution, which states that the independence of the Indonesian state is due to the blessing of the Almighty God. The opening of the 1945 Constitution is a substantial agreement among the founders of the nation, which forms the basis of the state-building, and the embodiment of the nation's founders.

Importance: It is expected that the transcendental paradigm elucidated in this article can be an alternative solution to overcome the Indonesian legal crisis that can mislead human civilization.

Originality/novelty: Orientation of Transcendental paradigms in the principle of Pancasila can be the answer to Indonesia's legal problems that tend to be power-oriented.

Keywords: Paradigm, Transcendental Law, Pancasila

\section{INTRODUCTION}

The current law in Indonesia is actually derived from Western law in the Europe continental (positivist) paradigm. Positivistic philosophy was taught by two famous exponents, namely Henri Saint-Simon (1760-1825) and Auguste Comte (1798-1857). In 
England, this type of philosophy was developed by Herbert Spencer. Positivism is an understanding that demands that every methodology, which is thought to find the truth, should treat reality as something that exists as an object, which must be released from any metaphysical pre-conception that is subjective in nature. ${ }^{1}$

The positivistic philosophy then also influenced the field of law. To be applied to the law thought, positivism also requires the release of meta-juridical thought about law as adopted by natural law exponents. Therefore, every legal norm must exist in its objective nature as positive norms, affirmed as a concrete contractual agreement between the community members (or their representatives). Law is no longer conceptualized as a metaphorical (abstract) moral meta-juridical principle of the nature of justice, but ius that has been positivated as a lege or lex, in order to guarantee certainty of 'what is counted as law' and 'what even though normative must be stated as things that are not counted as law $: 2$

Formally, the Indonesian nation recognized and obtained Legal Studies firstly from the Dutch with the establishment of Rechtsschool in 1909, which was later developed into the Rechtshogeschool in Jakarta in 1924. The Legal Studies taught by itself were the Dutch National Law that must have been adjusted to the condition of the Dutch East Indies at that time. In this way, the content of the legal knowledge given in the law faculties more or less continues to the Rechtshogeschool tradition that is the continental European tradition. This scientific tradition has very old age that has developed since the days of Ancient Rome.

This tradition has an impact on Indonesia's legal life that tends to have a positivistic paradigm, which leads to power. ${ }^{3}$ The way of thinking and law has caused a crisis in the law. This condition evoked a materialistic and atheistic way of law. Such a method of law will undoubtedly lead danger that is misleading the human civilization and, of course, we should prevent it and search the alternative solutions.

The existence of a paradigm crisis built by western positivism has shaken human belief in the civilization of legal science as a representation of complete reality. The paradigm crisis has even raised new concerns about the origin of nature in life, human

${ }^{1}$ M. Syamsudin, Landasan Ontologi Ilmu Hukum Profetik, in M. Syamsudin (Editor), Ilmu Hukum Profetik, Gagasan Awal, Landasan Kefilsafatan dan Kemungkinan Pengembangannya Diawal Post Modern, FH UII Press, Yogyakarta, 2013, p. 85

${ }^{2}$ Ibid, hlm. 87.

${ }^{3}$ Catur Yunianto and Arie Purnomosidi, Paradigma Transendental Perdagangan Bebas Dalam Perspektif Sistem Hukum Pancasila, Dalam Absori, et al. (Editor), Hukum Transendental, Pengembangan dan Penegakan Hukum di Indonesia, Genta Publishing, Yogyakarta, 2018, p. 301. 
relations with nature, and human relations with The Creator. Starting from anxiety that in turn arises the awareness to leave the reductionistic and atomistic perspective, which is often identified with the scientific method, and along with the scientific method. Along with that, the new paradigm needs to be presented, namely transcendental paradigm thinking. ${ }^{4}$

Transcendental paradigms that contain divine values are an inseparable part of Pancasila, in which Pancasila is the spirit of the nation (volkgeist) of Indonesian. Pancasila as a volkgeist is then formalized into the law in Indonesia. The transcendental value in national law called Pancasila can be viewed from the first principle of Pancasila and in the preamble to the 1945 Constitution.

\section{FORMULATION OF THE PROBLEM}

Concerning the description above, the problem in this article is how the transcendental legal paradigm in the Pancasila legal system is?

\section{RESEARCH METHODOLOGY}

This research was a doctrinal research by using philosophical and theoretical approaches. This approach was used because this article aims to examine the transcendental paradigm in Pancasila philosophically.

\section{DISCUSSION}

\section{The Pancasila Legal Paradigm.}

Pancasila is a legal basis that is grounded from the Indonesian spirit (volkgeist). Legal ideals originating from volkgeist are ideas, intentions, inventions, and thoughts relating to law or perceptions about the meaning of the law, which in essence consists of three elements. Those elements are justice, usefulness, and legal certainty. ${ }^{5}$ Thus, Pancasila is a law that is based on the values of life and culture of the Indonesian people that are formulated into Pancasila, namely the value of God, the value of Humanity, the value of

${ }^{4}$ Nurul Hakim and Ike Sumawaty, Imlementasi Hukum Transendental Dalam Bentuk Aturan Perundang-Undangan di Indonesia, Absori, et al. (Editor), Op Cit, p. 332

${ }_{5}$ Bernard Arief Shidarta, Ilmu Hukum Indonesia (Upaya Pengembangan Ilmu Hukum Sistematik Yang Responsif Terhadap Perubahan Masyarakat), Genta Publishing, Yogyakarta, 2013, p. 96 
Unity, the value of Deliberation and the value of Justice. The translation of the five values in the Pancasila law are as follow:

1. Value of God. This principle implies that Pancasila is a legal that is full of divine and morality values, as well as religious tolerance.

2. Value of Humanity. It means that Pancasila is a legal order that respects human values, namely laws that uphold human dignity, which humanize human beings.

3. Value of Unity. It implies that Pancasila is a law that guarantees the integration of the nation and state.

4. Value of Democracy. The value of democracy here means that the formation of law in Indonesia must prioritize democracy. Democracy is based on democratic and deliberation values that absorb people's aspirations.

5. Value of Justice. It implies that Pancasila is a law that aims to create prosperity and justice for the people of Indonesia, both in legal justice and economic (social) justice.

The five values in Pancasila reveal the fundamental values as well as being the five operational principles in living life, including in organizing state and law life activities in Indonesia. Pancasila is a law that is by the characteristics of the people in Indonesia. It is the characteristics of Indonesian society that are monodualistic and pluralistic.

Based on the ideals of the law, the Pancasila is a legal order that is core to:

1) Belief in the Almighty God;

2) Respect for human dignity;

3) Nationality and archipelago insight;

4) Equation and eligibility;

5) Social justice;

6) Moral and noble character;

7) Participation and transparency in the process of making public decisions. ${ }^{6}$

According to Arief Sidharta, the goal of the Pancasila is to realize humanity's protection, which is to protect human beings passively by preventing arbitrary and active actions by creating humane social conditions that enable the social process to take place naturally. Thus, every human being has an ample and equal opportunity to develop the full

\footnotetext{
${ }^{6}$ Ibid, p. 99.
} 
potential of humanity as well as to develop and maintain the humanitarian character and moral ideals of the people based on the belief in the Almighty God. ${ }^{7}$

\section{The transcendental paradigm in Pancasila}

For Indonesia, transcendental values have been reflected in the Ideology of Pancasila. Hence, Pancasila contains transcendental values, which are sourced from divine values in religion, ${ }^{8}$ ethics, and morality law. ${ }^{9}$ When drawn in the history of the formation of the Pancasila, Pancasila is very substantive in transcendental values because it is built on the religious spirit. There is no single literature that can prove that Pancasila, in the manufacturing process, is free from transcendental considerations. Therefore, the meaning of Staatsfundamental-norm stagnation inherent in Pancasila must be reinterpreted by opening the opportunity to at least provide a tighter transcendental content in the official interpretation of Pancasila. There is not the slightest concern from this integration process that threatens the existence of Indonesia. On the contrary, the things that occur will be able to provide new expectations and tremendous energy in the life of the nation that has been experiencing acute pessimism in responding to all issues, including the law.

The position of Pancasila as an ideology in the legal system is placed as a paradigm that is used as a reference and source of value and orientation in the formation of law to regulate public order. The paradigm term used to place the position of Pancasila contains an understanding as a result of the process of philosophical study. Ian G Barbour's approach can be used as a comparison that science and religion can be juxtaposed by combining certain aspects so that they can relate harmoniously. Therefore, Pancasila, as a paradigm, can also be integrated with other paradigms, but it still follows the epistemological path that can be accounted. ${ }^{10}$

Pancasila is the basis of justification for Indonesian law based on the epistemology of empirical-intuition-revelation ratios. The entry of religious intuition (transcendental) as

\footnotetext{
${ }^{7}$ Bernard Arief Shidarta, Op Cit, p. 105.

${ }^{8}$ Paisol Burlian, Hakikat Pembangunan Hukum, Jurnal Miqot, Vol. XXXVIII, No. 1, Januari-Juni 2014, hlm. 149.

${ }^{9}$ Ethics and morals are two different things. Ethics is the science of morals. Or often said, ethics is a philosophy of moral teaching. Meanwhile, morals are the whole rules, principles, or laws that take the form of rules and prohibitions. Therefore, ethics is different from morals. Moral teaching answers the question of how people should live, what is permissible, what is not permissible, and what must be done, while ethics answers the question of how the moral question is answered. See Khudzaifah Dimyati, et al, Hukum dan Moralitas Basis Epistimologi Paradigma Rasional H.L.A. Hart, Genta Publishing, Yogyakarta, 2017, p. 14

10 Sugeng Wibowo, Integrasi Epistimologi Hukum Transendental Sebagai Paradigma Hukum Indonesia, Jurnal Hukum Legal Standing, Vol. 1 No.1, March 2017, p. 76.
} 
a paradigm in the legal of Pancasila is expected to be able to complete the science of law and provide spirit and soul to the development of Indonesian law. ${ }^{11}$

The efforts to study and understand the law must put more emphasis on the things that are substantive and transcendental by grounding on social facts that are inseparable from religious, ethical, and moral values but without ignoring the criticality of a theory offered as human efforts.

The spiritual perspective of Science, including law, is not only based on the truth of qauliyyah (God verse), the level of truth at the level of haqq al-yakin (proven to be true), which is collected in the Qur'an and Hadith. It is also based on the truth obtained with the ability of human potential through ulum naqliyyah (based on Qur'an and Hadith), namely contemplation, reasoning, and discourse that develop in society. Humans explore, process, and formulate knowledge with the aim of not only for knowledge but also for policy, the benefit of the broader community, with the blessing, grace, and mercy of Allah. ${ }^{12}$

The relationship between humans and the law cannot be separated. Therefore, in the development of Indonesian law must go through an understanding of human nature. Notonagoro shows human nature integrally. The essential nature of human beings in the State of the Republic of Indonesia has Pancasila as a monopluralis (compound-single). Humans as monopluralist beings by Notonagoro are interpreted as creatures who also have three origin of natures as follows: (1) Composition of monodualist natures: humans as creatures composed of body and soul, (2) The monodualist natures: humans as individual creatures and social creatures, and (3) The position of monodualist nature: human beings as independent beings and creatures created by the Almighty God. ${ }^{13}$

Thus, the development of national law that is based on the transcendental paradigm can create a dignified law, namely a law that humanizes human beings. It means that the law enforces and upholds human values according to their nature and purpose in life. It is because humans as a creature of the Almighty God as stated in the second principle of Pancasila, that is a just and civilized humanity, has the value of recognition of human

11 Abdul Ghofur Anshori, Menggali Makna Sistem Hukum Dalam Rangka Pembangunan Ilmu Hukum Dan Sistem Hukum Nasional, Orasi Ilmiah Dies Natalis Fakultas Hukum UGM ke-62 Tahun 2008, p. 5

${ }^{12}$ Absori, Op Cit, p. 45.

${ }^{13} \mathrm{Ibid}$, p. 12. 
dignity and all the rights and obligations and obtain a fair treatment of humans, towards themselves, the natural surroundings, and against the God. ${ }^{14}$

Transcendental values that are desired in the Pancasila are positive God principles that glorify brotherhood and justice based on the truth of God's power, the Almighty Essence, the determinant of life, and human life. Based on the transcendental paradigm, it is expected that national law can realize the goal for the benefit of humanity/people of Indonesia.

The Pancasila, which is the transcendental paradigm, is expected to be able to carry out expressive and instrumental functions. ${ }^{15}$ The expressive function is expressing worldview, cultural values, divine values, and justice. Meanwhile, the instrumental function is to create and maintain order, stability, and predictability, as a means to preserve cultural values, divine values, and justice values in order to create a civilized society and as a means of community renewal (encouraging, canalizing and directing community change).

Thus, the development of national law that is based on the transcendental paradigm can create a dignified law, ${ }^{16}$ namely a law that humanizes human beings. It means that the law enforces and upholds human values according to their nature and purpose in life. It is because humans as a creature of the Almighty God as stated in the second principle of Pancasila, that is a just and civilized humanity, has the value of recognition of human dignity and all the rights and obligations and obtain a fair treatment of humans, towards themselves, the natural surroundings, and against the God. ${ }^{17}$

As a consequence of the recognition of the Almighty God, the Divine values must inspire, illuminate, and radiate into the life of law in Indonesia. The light of the spirit of God in the legal life in Indonesia is a form of recognition of the Indonesian nation for its creator. ${ }^{18}$ The meaning of this creation is that the universe with everything in it as a harmonious intertwined whole created by the Almighty God. Humans were created by the

\footnotetext{
${ }^{14}$ Taryono and Arie Purnomosidi, Development of National Law in Perspective Trancendental Paradigm, Surakarta Law and Society Journal, Vol. 1 No. 2, February 2019, p. 94 189

${ }^{15}$ Bernard Arief Shidarta, Refleksi Tentang Struktur Ilmu Hukum, Mandar Maju, Bandung, 2000, p.

16 Terkait dengan hukum bermartabat lihat Teguh Prasetyo, Keadilan Bermartabat Perspektif Teori Hukum, Nusa Media, Bandung, 2015.

${ }^{17}$ Teguh Prasetyo and Arie Purnomosidi, Membangun Hukum Berdasarkan Pancasila, Nusa Media, Bandung, 2014, p.163.

18 Suparman Usman, Hukum Islam, Asas-Asas dan Pengantar Studi Hukum Islam Dalam Tata Hukum Indonesia, Gaya Media Pratama, 2001, p. 127.
} 
Almighty God also. Humans come from God, and the ultimate goal of life is to return to its original source because it is devoted, and serving God is a reasonable human obligation and requirement. ${ }^{19}$

The spirit of the Preamble to the 1945 Constitution is then formulated and translated into the body of the 1945 Constitution, namely in Article 29 of the 1945 Constitution, which states that:

(1) The state is based on the Almighty God;

(2) The state guarantees the independence of each population to embrace their respective religions and to worship according to their religion and beliefs.

The formulation of Article 29 paragraph (1) of the 1945 Constitution, implies that the State of Indonesia is a state of religion but not a state of religion based on a particular religion. It suggests that the Indonesian state based on Pancasila is not a secular state that separates religious affairs from state affairs at all. Thus, the state of Indonesia adheres to a middle way that is neither a religious state nor a secular state, but a religious state. ${ }^{20}$

Then, the Article 29 paragraph (1) of the 1945 Constitution is applied to the life of the law in Indonesia, which includes:

1) laws and regulations in Indonesia. It is in which every law and regulation in Indonesia is always preceded by the phrase "By the Grace of God Almighty". The sentence with the Grace of God Almighty is the foundation that colors the contents of the law (laws and regulations) in Indonesia with something that comes from divine values because it will appear to be more related to the God that is just, humanist ${ }^{21}$ and dignified. It aims to provide protection, expediency, justice for the people of Indonesia.

2) justice in Indonesia. Transcendental value in the justice system in Indonesia can be viewed from the provisions of Article 2 paragraph (1) of Law no. 48 of 2009 concerning Judicial Power, which regulates that justice is conducted for Justice based on the Almighty God. Then, Article 2 paragraph (1) of Law No. 48/2009 is applied in a court ruling containing the clause "For justice based on the Almighty God". According to Djohansyah, the court's decision that contained the decree "For justice based on the

19 Bernard Arief Shidarta, Filsafat Hukum Pancasila, Materi Perkuliahan Mata Kuliah Sistem Filsafat Hukum Indonesia, Program Pascasarjana Program Studi Ilmu Hukum Universitas Parahyangan, Bandung, 2006.

${ }^{20}$ Lihat Piatur Pangaribuan and Arie Purnomosidi, Negara Hukum Pancasila Dalam Kerangka NKRI, Cakrawala Media, Surakarta, 2012, p. 173.

${ }^{21}$ Nurul Hakim and Ike Sumawaty, Op Cit, p. 334. 
Almighty God" has the consequence that the judgment of the judge/court that is born from his conviction. It eventually becomes part of the accountability of the moral attitude of the judge addressed to God Almighty, the figure that it is believed to be omniscient in every human heart. The judge is God's representative on earth, whose consequences must be held accountable for his decision to God. A judge's hammer tapping cannot be done based on the interests that surround him but must be done solely for God's justice. ${ }^{22}$

Meanwhile, Sulistyowati Irianto stated that the meaning of the transcendence of the phrase "For justice based on the Almighty God" is not just an empty slogan. It is not just a mere supplement of the judge's decision. Judges must live the principle of transcendence inherent in their profession. The transcendence value of the judge's profession is related to the meaning of the profession as a field of worship. It is called the worship field because it has lived the principle of transcendence as an underlying philosophy that is in line with its religious beliefs. ${ }^{23}$ Furthermore, according to Bismar Siregar, judicial differences in Indonesia are different from those of other countries. In Indonesia, it is obligatory to hold judicial proceedings in the name of God. In other countries, it may be the opposite. ${ }^{24}$

\section{CONCLUSION}

Transcendental paradigms that contain divine values are an inseparable part of Pancasila. The transcendental value in Pancasila can be viewed from the first principle formulation of Pancasila, namely "The Almighty God" and the phrase in the opening of the 1945 Constitution "By the Blessing of God's Grace". As a consequence of the recognition of the Almighty God, the divine values must inspire, illuminate, and radiate into the life of law in Indonesia. The light of the spirit of God in the legal life in Indonesia is a form of recognition of the Indonesian nation for its Creator.

In the Indonesian context, the paradigm of God-based law does not stop with legal pluralism that values differences as a natural social construction but transcends them utilizing integration through legal compromise, which accommodates divine values. The

\footnotetext{
${ }^{22}$ Absori, Epistimologi Dan Legalisasi Hukum Transendental, Op Cit, p. 29-30

${ }^{23}$ Farid Wajdi, Makna Transendensi Demi Keadilan Berdasarkan Ketuhanan Yang Maha Esa, http://farid-wajdi.com/detailpost/makna-transendensi-demi-keadilan-berdasarkan-ketuhanan-yang-maha-esa, accessed on July 17, 2018.

${ }^{24}$ Ibid.
} 
method used is applied utilizing interobjectivity generated through the inner experience of religion, civil will, policy, wisdom, the rule of law, and cultural identity. ${ }^{25}$

\section{REFERENCES}

\section{Book}

Absori, Epistimologi Dan Legalisasi Hukum Transendental, Dalam Absori, et al.(Editor), Hukum Transendental, Pengembangan dan Penegakan Hukum di Indonesia, Genta Publishing, Yogyakarta, 2018.

Absori, et al., Hukum Profetik, Kritik Terhadap Paradigma Hukum Non Sistemik, Genta Publishing, Yogyakarta, 2015.

Bernard Arief Shidarta, Refleksi Tentang Struktur Ilmu Hukum, Mandar Maju, Bandung, 2000.

, Filsafat Hukum Pancasila, Materi Perkuliahan Mata Kuliah Sistem Filsafat Hukum Indonesia, Program Pascasarjana Program Studi Ilmu Hukum Universitas Parahyangan, Bandung, 2006.

, Ilmu Hukum Indonesia (Upaya Pengembangan Ilmu Hukum Sistematik Yang Responsif Terhadap Perubahan Masyarakat), Genta Publishing, Yogyakarta, 2013.

Catur Yunianto and Arie Purnomosidi, Paradigma Transendental Perdagangan Bebas Dalam Perspektif Sistem Hukum Pancasila, Dalam Absori, et al. (Editor), Hukum Transendental, Pengembangan dan Penegakan Hukum di Indonesia, Genta Publishing, Yogyakarta, 2018.

Heddy Shri Ahimsa Putera, Paradigma Profetik (Sebuah Konsepsi), Dalam M. Syamsudin (Penyunting), Ilmu Hukum Profetik (Kemungkinan Pengembangannya di Era Postmodern), FH UII Press, Yogyakarta, 2013.

Khudzaifah Dimyati, et al, Hukum dan Moralitas Basis Epistimologi Paradigma Rasional H.L.A. Hart, Genta Publishing, Yogyakarta, 2017.

Khudzaifiah Dimyati, Pemikiran Hukum: Kontruksi Epistimologis Berbasis Budaya Hukum Indonesia, Genta Publishing, Yogyakarta, 2014,

Nurul Hakim and Ike Sumawaty, Imlementasi Hukum Transendental Dalam Bentuk Aturan Perundang-Undangan di Indonesia, Absori, et al. (Editor), Hukum Transendental, Pengembangan dan Penegakan Hukum di Indonesia, Genta Publishing, Yogyakarta, 2018.

Piatur Pangaribuan and Arie Purnomosidi, Negara Hukum Pancasila Dalam Kerangka NKRI, Cakrawala Media, Surakarta, 2012.

25 Absori, et al., Hukum Profetik, Kritik Terhadap Paradigma Hukum Non Sistemik, Genta Publishing, Yogyakarta, 2015, p. 388. 
Robert Audi, The Cambridge Dictionary of Philosophy, Second Edition, Cambridge University Press, 1999.

Suparman Usman, Hukum Islam, Asas-Asas dan Pengantar Studi Hukum Islam Dalam Tata Hukum Indonesia, Gaya Media Pratama, Surakarta, 2001.

M. Syamsudin, Landasan Ontologi Ilmu Hukum Profetik, Dalam M. Syamsudin (Penyunting), Ilmu Hukum Profetik, Gagasan Awal, Landasan Kefilsafatan dan Kemungkinan Pengembangannya Diawal Post Modern, FH UII Press, Yogyakarta, 2013

Teguh Prasetyo, Keadilan Bermartabat Perspektif Teori Hukum, Nusa Media, Bandung, 2015.

Teguh Prasetyo and Arie Purnomosidi, Membangun Hukum Berdasarkan Pancasila, Nusa Media, Bandung, 2014.

\section{Journal}

Paisol Burlian, Hakikat Pembangunan Hukum, Jurnal Miqot, Vol. XXXVIII, No. 1, January-June 2014.

Sugeng Wibowo, Integrasi Epistimologi Hukum Transendental Sebagai Paradigma Hukum Indonesia, Jurnal Hukum Legal Standing, Vol. 1 No.1, March 2017.

Taryono and Arie Purnomosidi, Development of National Law in Perspective Trancendental Paradigm, Surakarta Law and Society Journal, Vol. 1 No. 2, February 2019.

\section{Article}

Abdul Ghofur Anshori, Menggali Makna Sistem Hukum Dalam Rangka Pembangunan Ilmu Hukum Dan Sistem Hukum Nasional, Orasi Ilmiah Dies Natalis Fakultas Hukum UGM ke-62 Tahun 2008.

Absori, Epistimologi Ilmu Hukum Transendental dan Implementasinya dalam Pengembangan Program Doktor Ilmu Hukum, Disampaikan pada Seminar Nasional dengan Tema "Pengembangan Epistimologi Ilmu Hukum", in Universitas Muhammadiyah Surakarta, April 11, 2015.

Pemikiran Hukum Transendental Dalam Konteks Pengembangan Ilmu Hukum Indonesia, Proseding Seminar Nasional Transendensi Hukum, Prospek Dan Implementasi, Genta Publishing, Yogyakarta, 2017.

Heddy Shri Ahimsa Putera, Paradigma, Epistimologi dan Etnografi Dalam Antropologi, Artikel Ceramah "Perkembangan Teori dan Metode Antropologi, Departemen Antropologi, FISIP Unair, Surabaya, May 6-7 2011.

\section{Website}


Farid Wajdi, Makna Transendensi Demi Keadilan Berdasarkan Ketuhanan Yang Maha Esa, $\quad$ http://farid-wajdi.com/detailpost/makna-transendensi-demi-keadilanberdasarkan-ketuhanan-yang-maha-esa, accessed on July 17, 2018. 